Doi.10.33373/jmb.v2i1.2269

E-ISSN 2614-5944

Minda Baharu, Volume 2, No 1 Juli 2018

Hal. $8-14$

\title{
PELATIHAN PEMBUATAN STUDI KELAYAKAN DAN PROPOSAL KREDIT BAGI USAHA MIKRO KECIL DAN MENENGAH (UMKM) (Studi Kasus: Kelurahan Sagulung Kota Kecamatan Sagulung Kota Batam Tahun
} 2017)

\section{FEASIBILITY STUDY AND CREDIT PROPOSAL TRAINING FOR MICRO, SMALL, MEDIUM ENTERPRISES (UMKM) (A Case Study: Sagulung Kota Sub-District, Sagulung District, Batam, 2017)}

\author{
Nurhayati \\ Program Studi Ilmu Pemerintahan Fakultas Ilmu Sosial dan Ilmu Politik \\ Universitas Riau Kepulauan Batam \\ nurhayati_ip@yahoo.com
}

\begin{abstract}
Abstrak
Penyusunan studi kelayakan suatu usaha adalah merupakan langkah terakhir yang perlu dilakukan sebelum suatu usaha mulai dilaksanakan hingga sampai kepada keputusan bahwa gagasan usaha tersebut dapat dilaksanakan atau dibatalkan. Sebelumnya terlebih dahulu dilakukan identifikasi dan formulasi sampai dengan keputusan perlu tidaknya dilakukan studi kelayakan. Penyusunan studi kelayakan untuk usaha mikro, kecil dan menengah (UMKM) di negara berkembang termasuk di Indonesia masih sangat jarang dilaksanakan. Hal ini disebabkan antara lain karena : Kondisi modal terbatas sedangkan biaya untuk menyusun studi kelayakan relatif tinggi., Kesadaran dan pengetahuan akan pentingnya manfaat suatu studi kelayakan masih belum tumbuh dengan baik, Pengusaha masih beranggapan bahwa studi kelayakan hanya perlu untuk mengajukan dana kredit kepada bank saja. Aspek-aspek yang penting dan menentukan terhadap kelayakan suatu rencana usaha, adalah aspek teknis produksi, aspek pasar dan pemasaran, aspek hukum, aspek sosial ekonomi, aspek manajemen, aspek keuangan dan aspek lingkungan. Hasil analisis semua aspek tersebut di atas, harus sampai kepada kesimpulan kelayakan yang menyeluruh.
\end{abstract}

Kata Kunci : Studi Kelayakan, Kredit, dan UMKM

\begin{abstract}
Preparation of a business feasibility study is the last neccesary step to do before begining a business until final decision comes. At beginning, identification and formulation must be done till final deciation comes. The preparation of feasibility studies for micro, small and medium enterprises (UMKM) in developing countries including Indonesia was still very rarely implemented. This was due to the fact that: The limited fond condition whereas preparing a feasibility study cost was high. Awareness and knowledge of feasibility study importance was in low level. Employers still thought that the feasibility was just credit aplication requirement. The important and decisive aspects of the feasibility of a business planing were technical aspects of production, market and marketing aspects, legal aspects, socioeconomic aspects, management aspects, financial aspects and environmental aspects. The results of those aspects analysis, must come to conprehensive and feasibility conclusion.
\end{abstract}


Keywords: Feasibility Study, Credit, and UMKM

\section{PENDAHULUAN}

Kelurahan Sagulung Kota adalah merupakan salah satu kelurahan di Kecamatan Sagulung, Kota Batam Propinsi Kepulauan Riau, dengan jumlah penduduk mencapai 30.304 jiwa yang tersebar di 17 RW dan 90 RT. Keluarahan Sagulung Kota juga merupakan kelurahan dengan kepadatan penduduk paling besar di Kecamatan Sagulung. Komposisi penduduk di Kelurahan Sagulung Kota di dominasi oleh laki-laki. Hal ini dapat dilihat dari angka sex rasio tertinggi di Kelurahan Sagulung Kota dengan nilai 113, yang berarti setiap 100 penduduk perempuan ada 113 laki-laki.

Sarana kesehatan di Kelurahan Sagulung kota cukup memadai. Dengan jumlah penduduk 30.304 jiwa tersedia prasarana kesehatan berupa 5 rumah bersalin/klinik kesehatan, 1 puskesmas, dan 8 posyandu. Masayarakat Kelurahan Sagulung Kota adalah merupakan masayarakat yang heterogen, umumnya adalah pendatang dari berbagai daerah yang ada di Indonesia, namun kondisi tersebut tidak mengurangi hubungan sosial yang ada di masyarakat.

\section{Gambaran umum Kelurahan Sagulung Kota di lihat dari kondisi Geografis.}

a. Kondisi Geografis

Kota : Batam

Kecamatan : Sagulung

Kelurahan : Sagulung Kota

Luas Wilayah : $\pm 65.000 \mathrm{~m}^{2}$

Jumlah RW : 17

Jumlah RT : : 90

Adapun batas wilayah Sagulung Kota, sebagai berikut ;

- Sebelah Timur : Kelurahan Sei. Langkai

- Sebelah Barat : Kelurahan Sungai Lekop

- Sebelah Selatan : Kelurahan Sungai Pelunggut

- Sebelah Utara : Kelurahan Buliang 
Wilayah Kelurahan Sagulung Kota terdiri dari beberapa kompleks perumahan, kavling

siap bangun juga ada beberapa perusahaan yang berada dilingkungan Sagulung Kota disamping itu juga terdapat pasar. Beberapa pembangunan infrastruktur tidak merata sehingga sering terjadi banjir.

Peta Keluarahan Sagulung Kota

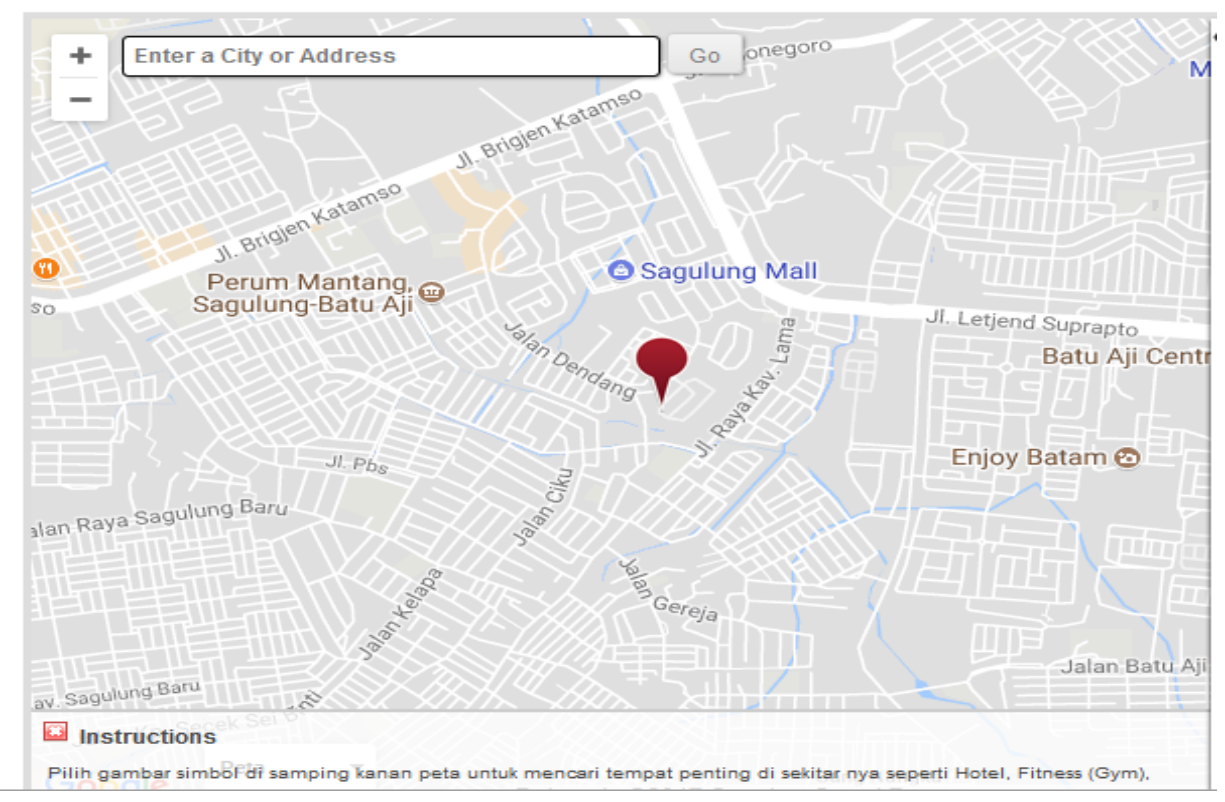

Gambar 1. Peta Keluarahan Sagulung Kota

Langkah pertama yang biasa digunakan dalam persiapan dan analisis suatu usaha adalah melakukan studi kelayakan untuk memperoleh informasi yang jelas dalam menentukan dimulainya perencanaan usaha (Gittinger,1986). Dengan kata lain, agar pelaksanaan usaha berhasil baik, dapat memberikan keuntungan baik kepada pengusaha maupun penyandang dana (bank) dan lembaga terkait lainnya, perlu adanya rencana usaha dan perhitungan yang matang berupa suatu studi kelayakan yang dibuat secara professional.

Upaya pengembangan dan pemberdayaan Usaha Mikro, Kecil dan Menengah (UMKM) di Kelurahan Sagulung Kota dewasa ini mendapat perhatian yang cukup besar dari berbagai pihak, baik pemerintah, perbankan, swasta, lembaga swadaya masyarakat maupun 
perguruan tinggi. Hal ini dilatarbelakangi oleh besarnya potensi UMKM yang perlu diefektifkan sebagai motor penggerak perekonomian.

Pembinaan dan pengembangan terhadap UMKM di Kelurahan Sagulung Kota, dimaksudkan adalah merupakan satu kesatuan proses yang di dalamnya mencakup tiga unsur yaitu menumbuhkan, memelihara dan megembangkan. Proses pelaksanaan pembinaan oleh secara partisipatif, bahwa segala sesuatu yang berhubungan dengan pembinaan (materi, metode dll) harus selalu bertumpu pada kebutuhan UMKM.

Bentuk kegiatan pembinaan dan pengembangan disini adalah melakukan pendampingan terhadap UMKM dengan memberikan bantuan teknis berupa pelatihan sesuai kebutuhan, arahan dan konsultasi. Dalam pelaksanaannya di lapangan berpedoman yaitu Melakukan identifikasi pada calon nasabah UMKM di Kelurahan Sagulung Kota/sentra/populasi usaha;

Berdasarkan pemikiran di atas, agar pemberdayaan UMKM bisa terarah maka penulis melaksanakan Kegiatan pendampingan pembuatan studi kelayakan dan proposal kredit bagi Usaha Mikro Kecil dan Menengah di Kelurahan Sagulung Kota Kecamatan Sagulung Kota Batam Propinsi Kepulauan Riau.

Jenis mata pencarian penduduk Kelurahan Sagulung Kota berdasarkan hasil Pemetaan yaitu buruh, Pedagang, pegawai swasta dan Pegawai Negeri Sipil (PNS). Dari beberapa jenis mata pencarian tersebut mayoritas penduduk wiraswasta, namun pengelolaan usahanya masih sangat sederhana, hal ini berdasarkan hasil observasi dan wawancara yang dilakukan, berdasarkan hasil wawancara tersebut, kelemahan dan permasalahan utama bagi UMKM yaitu modal dan akses mendapatkan pinjaman ke Bank, dikarenakan kurangnya pengetahuan UMKM tentang cara membuat studi kelayakan dan proposal kredit.

\section{METODOLOGI}

Adapun teknik dan metodologi yang digunakan dalam kegiatan pengabdian masyarakat ini adalah melalui pelatihan dengan teknik workshop dengan menggunakan alat 
bantu multimedia berupa laptop, LCD, dan yang menjadi sasaran kegiatan tersebut adalah masayarakat kelurahan Sagulung Kota yang bergerak dibidang UMKM.

\section{Keterlibatan Anggota dan Pendukung}

Peserta yang terlibat dalam kegiatan tersebut adalah 26 mahasiswa Universitas Riau Kepulauan dengan didukung oleh CV. Ava Berlian sebagai Narasumber. Jumlah peserta yang mengikuti kegiatan tersebut adalah sebanyak 15 UMKM dengan masing-masing mengirimkan minimal 2 utusannya.

\section{PEMBAHASAN}

Penyusunan proposal kredit untuk usaha mikro dan kelayakan usaha khususnya bagi usaha kecil dan menengah dengan menggunakan pedoman penyusunan proposal kredit dan kelayakan usaha. Dalam mempersiapkan penyusunan proposal kredit maupun kelayakan usaha harus dilakukan secara cermat dan akurat berdasarkan data yang dapat dihimpun.

\section{Menghubungkan UMKM dengan bank}

Kegiatan pendampingan untuk pembinaan yang mengandung misi pengembangan sebagai tujuan utama, maka kegiatan pendampingan untuk menghubungkan UMKM dengan bank sebenarnya memerankan fungsi jembatan penghubung. Langkah awal agar bangunan jembatan tetap kokoh, tentunya UMKM sangat berperan untuk selalu menjaga hubungan (komunikasi) dengan bank, disamping itu diharapkan selain mampu dan terampil dalam menilai kelayakan usaha dari UMKM calon nasabah tersebut, juga terampil dalam menilai dan menghitung kemampuan membayar kembali nasabah yang mengajukan pinjaman ke bank.

\section{Menghubungkan Usaha Mikro dengan Bank}

Kegiatan menghubungkan pengusaha mikro dengan bank sebenarnya salah satu alternatif mencari kemungkinan dimana pengusaha mikro mendapat akses bagi pembiayaan usaha yang biasanya diajukan ke Bank Perkreditan Rakyat (BPR). Hal ini karena sebagian besar BPR melayani segmen mikro, namun demikian beberapa bank umum dan Bank 
Doi.10.33373/jmb.v2i1.2269

E-ISSN 2614-5944

Minda Baharu, Volume 2, No 1 Juli 2018

Hal. 8-14

Pembangunan Daerah telah memperluas pangsa pasarnya ke segmen mikro seperti halnya yang telah dilakukan BPR.

Teknis menghubungkan dengan bank bagi pengusaha mikro menggunakan pendekatan kelompok dengan wadah KPM. Seperti diketahui bahwa KPM walaupun tergolong kelompok formal namun tidak mempunyai status hukum tidak seperti Koperasi atau Perseroan yang telah memiliki status hukum yang jelas. Oleh karena itu persyaratan pengajuan kreditnya harus terdapat kesepakatan yang ditanda tangani oleh masing-masing anggota seperti :

- kesepakatan tanggung renteng;

- surat kuasa mendebet tabungan bila terdapat anggota yang menunggak atau macet;

- surat kuasa kepada ketua untuk menyerahkan agunan anggota yang selanjutnya diserahkan ke bank dan diikat secara di bawah tangan; dan

- pernyataan bersedia untuk menabung sebesar $10 \%$ dari kredit yang diterima dan ditampung dalam rekening tersendiri (atas nama kelompok) dan selanjutnya dibekukan oleh bank.

Pengajuan kredit dibuat dalam satu proposal kredit yang jumlah kreditnya merupakan jumlah kumulatif pengajuan kredit seluruh anggota, kemudian setelah melalui proses analisa dan kunjungan on the spot ke kelompok, apabila disetujui maka kreditnya akan di tampung dalam satu rekening sehingga biaya dapat ditekan.

\section{Menghubungkan Usaha Kecil dan Menengah dengan Bank}

Teknis menghubungankan Usaha Kecil dan Menengah dengan Bank dilakukan secara individual, permohonan kreditnya dituangkan dalam Kelayakan Usaha yang dibuat secara komprehensif mencakup seluruh aspek seperti :

- $\quad$ Hukum : Tidak bertentangan dengan peraturan dan norma yang berlaku

- Teknis : Dapat dilaksanakan dengan baik dan lancar

- $\quad$ Manajemen: Dapat dikelola dengan baik 
Doi.10.33373/jmb.v2i1.2269

E-ISSN 2614-5944

Minda Baharu, Volume 2, No 1 Juli 2018

Hal. 8-14

- $\quad$ Finansial : $\quad$ Memberikan arus kas yang positif dan dapat menutup semua biaya serta memberikan keuntungan bagi pengusaha

- $\quad$ Sosial ekonomi : Memberikan manfaat bagi masyarakat

Dengan disusunnya kelayakan usaha tersebut maka bagi investor dapat memilih alternatif investasi dananya pada usaha yang menguntungkan. Sementara bagi perbankan sangat berguna dalam proses analisa untuk menentukan jumlah pinjaman yang akan diberikan dan untuk mengetahui likuiditas usaha tersebut dikaitkan dengan kemampuan membayar hutangnya.

Aspek-aspek yang penting dan menentukan terhadap kelayakan suatu rencana usaha, adalah aspek teknis produksi, aspek pasar dan pemasaran, aspek hukum, aspek sosial ekonomi, aspek manajemen, aspek keuangan dan aspek lingkungan. Hasil analisis semua aspek tersebut di atas, harus sampai kepada kesimpulan kelayakan yang menyeluruh, meliputi kelayakan, sebagai berikut
a. Kelayakan secara teknis dan produksi
b. Kelayakan dari aspek pasar dan pemasaran
c. Kelayakan secara hukum
d. Kelayakan dari aspek sosial dan ekonomis,
e. Kelayakan dari aspek manajemen dan sumber daya manusia
f. Kelayakan secara financial
g. Kelayakan dari aspek lingkungan

\section{KESIMPULAN}

1. Dengan adanya pelatihan pembuatan studi kelayakan dan proposal kredit, maka UMKM tidak memiliki alasan lagi dengan penambahan Modalnya.

2. Memudahkan dan membiasakan masyarakat pelaku UMKM dengan perbankan.

3. Menambah wawasan dan pengetahuan masyarakat pelaku UMKM tentang studi kelayakan dan proposal kredit.

4. Sebagai media informasi bagi pelaku UMKM daerah lainnya. 
Doi.10.33373/jmb.v2i1.2269

E-ISSN 2614-5944

Minda Baharu, Volume 2, No 1 Juli 2018

Hal. 8-14

\section{REFERENSI}

Andrianus Mooy (1990). Masalah Strategi, Perkreditan dan Pelayanan Perbankan. Lembaga Pengembangan Perbankan Indonesia, Jakarta.

Kadariah (1986). Evaluasi Proyek, Analisa Ekonomis. Edisi dua, LPEE - Universitas Indonesia, Jakarta.

Zulkarnaen Djamin (1984), Perencanaan \& Analisa Proyek, LPFE-Universitas Indonesia, Jakarta.

Saifuddin Sarief, E. (1995/1996), Penyusunan Proposal dan Studi Kelayakan Agribisnis. Program Inkubator Aggribisnis. Kerjasama Deptan-Badan Agribisnis dan Fakultas Pertanian Universitas Padjadjaran, Bandung. 